Session 3532

\title{
Colleges of Engineering and Colleges of Education: Successful Campus Collaborations
}

\author{
Douglas Gorham \\ Manager, Pre-college Education \\ IEEE Educational Activities \\ Barbara Coburn Stoler \\ Acting Managing Director \\ IEEE Educational Activities
}

\begin{abstract}
With the growing influence and increasing complexity of technology, the public must have a certain level of technological understanding to make informed decisions and to attain a reasonable quality of life. It is crucial that current and future teachers have the resources, skills, knowledge and support to empower students to make informed decisions as citizens, consumers, and as members of the workforce. Colleges of Engineering and Colleges of Education can lead in this effort. These collaborations will not only help future and current teachers acquire the necessary skills to teach technologically oriented subject matter, but can support engineering faculty with curricula reform and educational outreach. This session will feature: 1) a summary of "Taking the Lead: A Deans Summit on Education For a Technological World" attended by Deans of Engineering and Deans of Education, from the same institution, and 2) representatives from up to four universities discussing successful campus collaborations between Colleges of Engineering and Colleges of Education that have impacted the precollege education community and engineering curricula reform.
\end{abstract}

\section{Background}

The need for a technologically literate citizenry is increasing with the rapid innovations occurring in technology. Pre-college schools and districts are not able to stay abreast of these innovations. Engineers have been responsible for many of these innovations. It seems logical that by working together, university engineering schools and education schools are in a position to impact the level of technological literacy among pre-college students and current and future teachers and engineers.

\section{Deans Summit Overview}

Held in Baltimore on 1-2 October 2001, Taking the Lead: A Deans Summit on Education for a Technological World was the first time that Deans of Engineering and Deans of Education have formally met with the express purpose of formulating on-campus collaborations. Deans of Engineering and Deans of Education are in key positions to reflect the concerns of their faculty and to promote collaborative programs at their institutions. They can facilitate a variety of joint ventures that can help to prepare 
excellent teachers and engineers to meet the challenges of an increasingly technological society.

Approximately forty-seven institutions, from around the world, attended the Summit. During breakout group work Summit attendees developed: 1) common themes that will have broad impact on campus reform, and 2) individual campus action plans that focused on collaborations to improve pre-service education and engineering curricula reform. One clear theme that emerged from the Summit was to hold a follow-up conference that features "best practices" and successful campus collaborations.

\section{Panel Session Overview}

This panel session will showcase on-campus collaborations that enhance the level of technological literacy in the pre-college community and impacted engineering curricula reform. Representatives from up to four universities will describe their collaborative efforts and discuss how they overcame the barriers and constraints that arise when any new program is undertaken. Panelists will offer guidance on how colleges of engineering and colleges of education can work collaboratively to increase the level of technological literacy among the pre-college community and impact engineering curricula and instruction.

\section{DOUGLAS GORHAM}

Douglas Gorham is currently responsible for pre-college education programs for the IEEE Educational Activities Board. He taught high school science for 8 years in Illinois and served as a high school administrator for 18 years, including 12 years as a high school principal. As a principal Dr. Gorham: coordinated the planning and implementation of an electronics engineering program, was highly involved in the design and building of a new high school, added Advanced Placement programs, and developed and implemented interdisciplinary programs combining pre-calculus with physics and American Literature with American History.

\section{BARBARA COBURN STOLER}

Barbara Coburn Stoler is currently Acting Managing Director of Educational Activities for IEEE, responsible for programs in continuing education, pre-college education, and accreditation. Barbara has an A.B. degree in English Literature and Education from Douglass College of Rutgers University. She has an M.A. in American Literature from Drew University. Barbara taught elementary school in Newark, N.J. and Verona, N.J. for six years and was the originator and coordinator of a K-8 Gifted and Talented Education program in Rockaway, N.J. from 1977-1985. Following teaching she was consulting instructional designer developing corporate training materials for companies such as American Express, AT\&T and Bell Laboratories and a social studies editor for Silver Burdett Publishing, a division of Simon and Schuster. She is a member of the American Society of Training and Development (ASTD), the American Society of Association Executives (ASAE), the American Society for Engineering Education (ASEE), and the Council of Executives of Societies of Science and Engineering (CESSE). 